\title{
Current State of Selective Prevention Practice of Drug Abuse in Croatia
}

\author{
Dinka Caha \\ Center for social welfare Požega, Croatia \\ Helena Križan \\ Elementary school Petar Zrinski, Zagreb, Croatia \\ Irena Velimirović \\ Center for rehabilitation Zagreb, Croatia
}

\begin{abstract}
Drug use is a phenomenon which seriously disturbs the health and the ability to function socially and in a balanced manner for a large number of young people in Croatia who are at the most sensitive stage of their individual development (Petrović, 1983; as cited in Bouillet, 2007). The perspective of developmental psychopathology helps to create all-encompassing theoretical models that explain the development of problems related to drug abuse, identify the groups that have the highest risk and guide the creation of logical models for prevention programs. This paper offers a hypothesized model of development of addiction problems in adolescence from the perspective of developmental psychopathology and uses it as a tool to analyse the current state of selective prevention practice in Croatia. The national focal point for drugs and drug addiction is located within the Office for Combating Drug Abuse of the Government of the Republic of Croatia. This Office also runs a Database of projects and programs administered in the field of drug demand reduction. According to the database review performed by the authors on June 26th 2016, 57 selective prevention programs were identified that fit the criteria for being "selective" (according to the definition by Mrazek \& Haggerty, 1994). Among these, 15 selective prevention programs were identified as matching the criteria of "program" used by the US Department of Health and Human Services (US DHHS, 2013a \& 2013b). The suggested theoretical model was subsequently compared to the goals and activities of these programs.
\end{abstract}

Keywords: drug abuse, selective prevention, developmental psychopathology, prevention programs

\section{Introduction}

The results of the European School Survey Project on Alcohol and Other Drugs (ESPAD) for 2015 demonstrate a rising trend in the use of illegal drugs and alcohol, with the prevalence of alcohol use rising by 10 percentage points (ESPAD group, 2016). According to ESPAD results, Croatia is above the European average in five of eight key variables (cigarette use in the past 30 days, alcohol use in the past 30 days, heavy episodic drinking in the past 30 days, lifetime use of cannabis and lifetime use of inhalants) (ESPAD group, 2016). The results of the Health Behaviour in School-aged Children research project for 2014 also show that in Croatia $25 \%$ of 15 -year-old boys and $22 \%$ of 15 -year-old girls smoke at least once a week. Further, $40 \%$ of 15 -year-old-boys and $24 \%$ of 15 -year-old-girls have gotten drunk at least twice in their life and $19 \%$ of 15 -year-old boys and $11 \%$ of 15 -year-old girls have tried cannabis at least once in their life (Šimetin Pavić, 
Mayer, Musić Milanović \& Jovičić, 2016). Approximately 2 in 10 younger adults, aged 15-24 years, reported using cannabis during the past year (European Monitoring Centre for Drugs and Drug Addiction, 2017). Across all health institutions in Croatia, 7533 persons were registered for receiving treatment for substance abuse addiction in 2015, of which $484(6,3 \%)$ were under the age of 20 (Croatian Institute of Public Health, 2016).

An analysis of public expenditure for monitoring achievement of the objectives in the field of combating drug abuse in the Republic of Croatia has shown that the annual estimated total public expenditure in the field of combating drug abuse was between 702 and 742 million HRK or 0,2\% of the GDP (Budak, Jurlina Alibegović, Slijepčević \& Švaljek, 2013). Studies from other countries offer more insight into how costly drug abuse exactly is (e.g. more than $\$ 700$ billion annually in the USA, according to the National Institute on Drug Abuse; NIDA, 2015). This does not just include health care expenditures, but also work productivity loss, and costs associated with crime and accidents. The aforementioned data clearly show that the use of drugs among youth is a widespread phenomenon which is very costly and takes up much of a country's resources.

The Croatian National Strategy for Combating Drug Abuse 2012 - 2017 (Government of the Republic of Croatia, 2012) stresses the important role of prevention on all levels in strategic efforts to combat drug abuse. However, most of the efforts in implementation of this strategy are directed towards universal prevention programs, targeting the general population of children and youth (Ured za suzbijanje zlouporabe droga, 2015).

In the Croatian context, focus is more and more commonly being placed on the development of selective and indicated prevention programs, as these are found to be severely lacking. It is important to note that most of the prevention efforts in Croatia are in the domain of the civil sector and a huge portion of the prevention programs on all three levels (universal, selective and indicated) is being created and/or implemented by nongovernmental organizations (NGOs). The Office for Combating Drug Abuse of the Government of the Republic of Croatia is in charge of developing the drug policy and coordinating the activities of all the actors involved in the implementation of the national drug strategy. On June 26th 2016, we performed a review of the Database of projects and programs administered in the field of drug demand reduction which is run by the Office for Combating Drug Abuse (http://www. programi.uredzadroge.hr/). This review shows that, among the 531 prevention programs, there are only 57 selective prevention programs, which indicates the need for further development of these programs. Additionally, a review of the programs observed shows that they lack some basic program components. Many of the programs that were defined as implemented on a selective level of prevention by their authors were often in fact universal prevention programs.

In order to create effective programs for children and youth at risk of developing substance abuse problems which have a sound theoretical basis, one needs to consider all risk and protective factors and their relationships. This can be done with the help of theoretical models developed in the discipline of developmental psychopathology, which provide information about the relationships between some relevant factors, place an emphasis on early risk factors, give insight into the appropriate timing of intervention in the developmental trajectories, offer knowledge on the 
interplay of factors on all levels, help to identify the groups that have the highest risk, and guide the creation of logical models for prevention programs.

This paper provides an analysis of the current state of selective prevention practice in Croatia, offers a hypothesized model of the development of addiction problems in adolescence from a perspective of developmental psychopathology, and puts forward some guidelines for further development of selective prevention policy and practice in the field of substance abuse prevention.

\section{The perspective of developmental pathology in drug abuse/addiction research}

For years, the linear model (Robins, 1966) postulating that some features, such as difficult temperament, can become a behavioral problem in adolescence and an antisocial personality disorder in adulthood has been the dominant model in developmental psychopathology. However, this model was not adequate in explaining the complex process of development of various behavioral problems and mental illnesses. Sameroff \& Chandler (1975) performed a longitudinal research study which included a sample of young people from a community, following them from birth to young adulthood, with the aim of targeting risk factors in their developmental trajectory. As a result, they created a new developmental concept, the so-called transaction model. The main postulate of this model is that the constant in the child's development is not posed by a group of characteristics (a set of "traits") but the process by which these properties are held through the interaction between the child and his experiences over time (Sameroff, 1995).

The transaction process consists of variables that interact at the micro, meso and macro levels and through the development phases. The main perspectives of developmental psychopathology rely on the above-mentioned concept.

Drug abuse research and theory have become much more sophisticated over the last two decades, and some of the advancements parallel concepts that are part of the developmental psychopathology approach (Glantz, 2000). The application of the developmental psychopathology perspective to recent drug abuse research findings can provide a greater understanding of that information, and point to important areas of future research. Applying the concepts of developmental psychopathology as a basis for research and understanding of drug use and drug addiction (with an emphasis on young people) is much different from the previous attempts to define the precursors, risk factors and their interactions. The concepts of developmental psychopathology emphasize the need to understand the behavior of young people in a variety of contexts (school, leisure, family and friends) and the ways in which different risk factors (vulnerability factors) at the level of biology, temperament, cognitive factors and family environment interact in these contexts. A growing number of theoretical perspectives on drug use and addiction, from a developmental perspective, emphasize mutual and reciprocal influences of social, cultural, behavioral, neural and genetic factors (Dawes et al., 2000).

Equifinality and multifinality are two important principles in developmental psychopathology. Equifinality is the idea that a given outcome, in our case drug use and/or addiction, can be reached from multiple initial conditions and multiple processes or paths. Multifinality means that a given initial condition may lead to different outcomes (Cicchety \& Rogosch, 1996). The principle 
of equifinality helps us identify multiple antecedents and probable predisposing factors. There seem to be many paths that can lead to drug use, including drug-using peers (Santor, Messervey \& Kusumakar, 2010), family problems (Barrett \& Tirner, 2006), poor schooling (Townsend, Flisher \& King, 2007), neighborhood (Ross, Reynolds \& Geis, 2000), etc. Developmental psychopathology emphasizes the importance of appropriately timed interventions that should occur at a time when they will have maximal impact (Nation et al., 2003).

As a period of multiple transitions and developmental challenges, adolescence bears an increased risk of emotional and behavioral problems, including the use of psychoactive substances and addiction (Cicchetti and Rogosch, 2002). White, Xie, Thompson, Loeber \& Stouthamer-Loeber (2001) examined early psychopathology as a predictor of trajectories of drug use from ages 13-18 years. During the six years of research, they tested whether distinct measures of psychopathology and behavioral problems such as attention-deficit/hyperactivity disorder, oppositional defiant disorder, conduct disorder, depression, and violence assessed in early adolescence could prospectively predict level and change in alcohol and marijuana use. Higher levels of all of the types of psychopathology predicted higher levels of alcohol use. Only the conduct disorder predicted a linear growth in alcohol use, and none of the measures predicted growth in marijuana use. The results suggest that drug use prevention programs should target youths with early symptoms of psychopathology.

Sitnick, Shaw \& Hyde (2014) researched the developmentally salient risk and protective factors of adolescent substance use during early childhood and early adolescence on a sample of 310 low-income boys. They conducted a longitudinal study, and utilized data from assessments at ages $1.5,2,3.5,11,12,15$, and 17 in their project. Using structural equation modeling, they explored potential precursors to later substance use during adolescence. Child problem behavior and proximal family risk and protective factors (i.e., parenting and maternal depression) during early childhood, as well as child and family factors and peer deviant behavior during adolescence, were explored as potential precursors to later substance use during adolescence.

Their results revealed that early childhood risk and protective factors (i.e., child externalizing problems, mothers' depressive symptomatology, and nurturant parenting) were indirectly related to substance use at the age of 17 via risk and protective factors during early and middle adolescence 
(i.e., parental knowledge, externalizing problems, daring, peers' substance use). Based on these results, they have suggested a conceptual model of developmental risk factors for adolescent substance use (Figure 1).
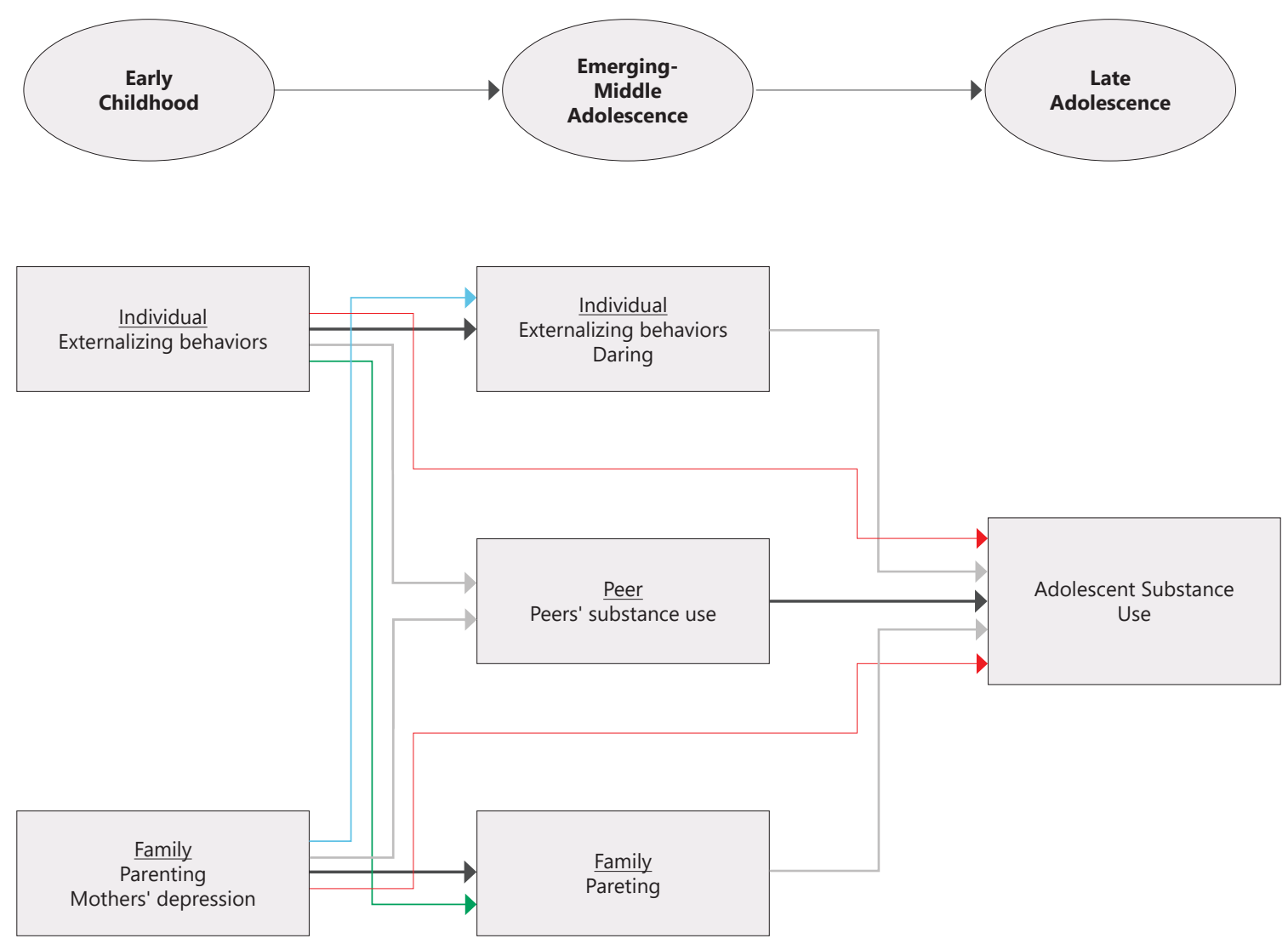

Figure 1 Conceptual Model of Developmental Risk Factors for Adolescent Substance Use (Sitnick Shaw \& Hyde, 2014).

Van Ryzin, Fosco \& Dishion (2012) conducted a study on family and peer influences on substance use from early adolescence to early adulthood. A large sample of early adolescents $(N=$ 998) was followed from age 12 to age 23. The authors tested direct and indirect effects of parental monitoring, family relationship quality, and association with deviant peers on change in substance use across time, at ages 12, 13, 15, 17, and 23 (Fig. 2). Youth reports were collected at these ages. Adolescents were asked to indicate the number of occasions they had used each substance (tobacco, alcohol, and marijuana) during the prior month. Findings suggest that both parents and peers have significant impact on substance use (tobacco, alcohol, and marijuana), with monitoring appearing to be more central in early adolescence, while the quality of family relationships tends to be more central in middle and late adolescence. 
These aspects of the family context demonstrated direct effects on substance use and some indirect effects on later use by way of deviant peer association, suggesting that parental monitoring and parent-youth relationships may play a role in an adolescent's choice of peers, which in turn can influence later substance use (Fig 2).

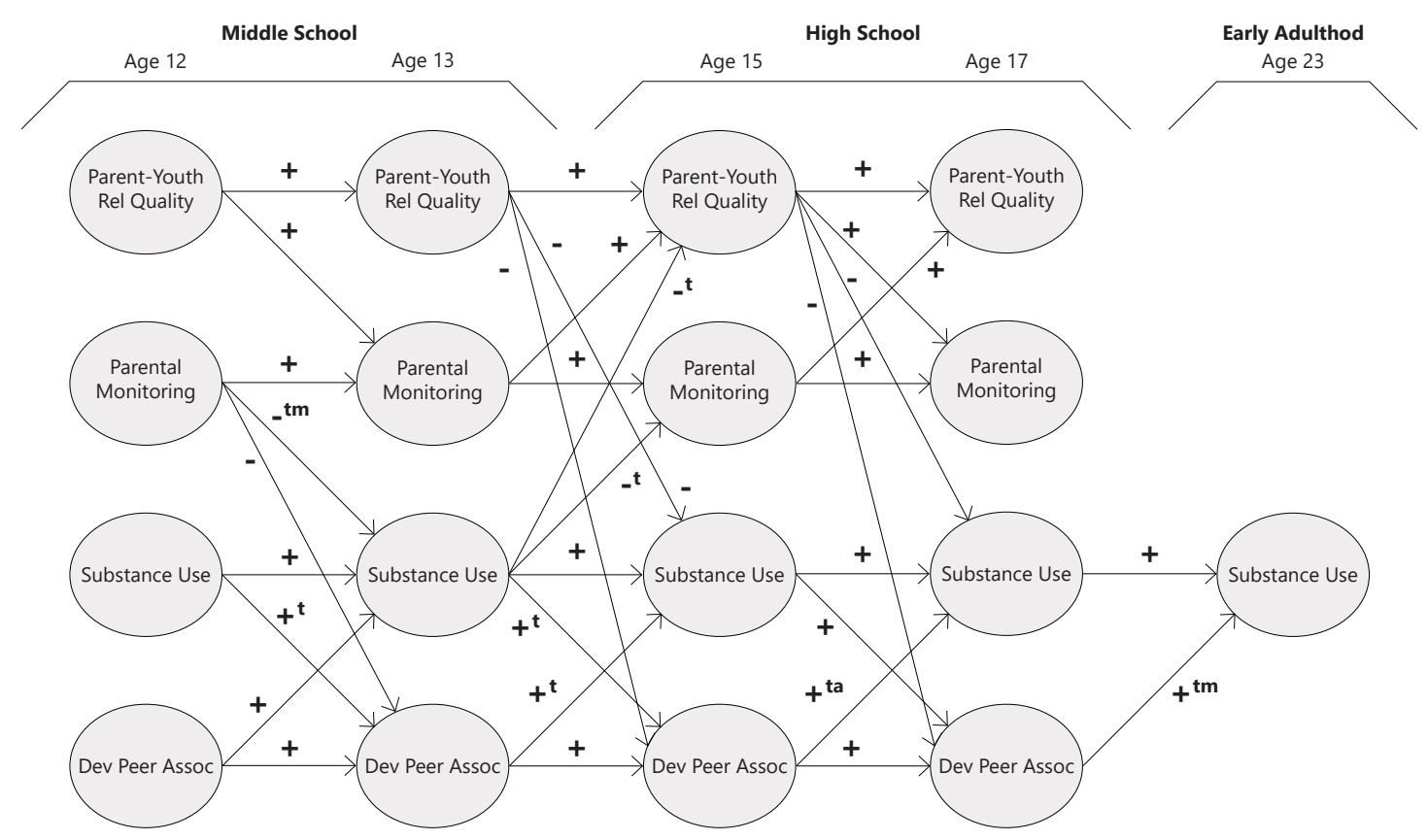

Figure 2 Fitted model with significant paths. Signs indicate direction of paths. Superscripts indicate that path limited to tobacco ( $t$ ), alcohol (a), or marijuana (m) use (Van Ryzin, Fosco \& Dishion, 2012).

Rogosch, Oshri and Cicchetti (2010) used a developmental cascade model in which they tested associations among child maltreatment, internalizing and externalizing psychopathology, social competence, and cannabis abuse and dependence symptoms in a longitudinal cohort $(N=415)$, across four developmental periods: ages 7 to 9,10 to 12,13 to 15 , and 15 to 18 . Results indicated significant paths from child maltreatment to early externalizing and internalizing problems and social competence, as well as to cannabis abuse and dependence symptoms in adolescence. Youth cannabis abuse and dependence symptoms were primarily directly related to child maltreatment and externalizing problems. Childhood internalizing symptoms contributed to decreases in social competence in later childhood, which predicted increases in externalizing problems in the late adolescent period.

Martel et al. (2009) put forward a hypothesized model of temperament pathways to adolescent substance abuse, from birth to adolescence. Their study participants were 674 children (486 boys) from 321 families, in an ongoing longitudinal high-risk study that began when children were 3 years old. They assessed temperament traits, such as reactive control, resiliency, and negative emotionality. Parent, teacher, and self-ratings of inattention/hyperactivity, disruptive behaviors, and substance abuse were also obtained. They found that temperament traits which increase the risk of developmental psychopathology during childhood as well as substance abuse during adolescence, were attention-deficit/hyperactivity disorder (ADHD) and disruptive behaviors. Low 
levels of childhood reactive control, but not resiliency or negative emotionality, were associated with adolescent substance abuse, mediated by disruptive behaviors.

Lynne-Landsman, Bradshaw and lalongo (2010) developed a cascade model of adolescent substance use trajectories and young adult adjustment. They used data from a community epidemiological research, with a sample of 678 urban, primarily African-American youth, followed from first grade through young adulthood (age 21). This study identified factors along the continuum from childhood through adolescence which created a cascade of associations across time, which in turn propelled individuals toward negative adjustment outcomes in young adulthood (see Figure 3). The results confirm and extend previous findings by indicating that the risk for adolescent substance use, young adult mental health problems, and criminal behavior begins in early childhood.

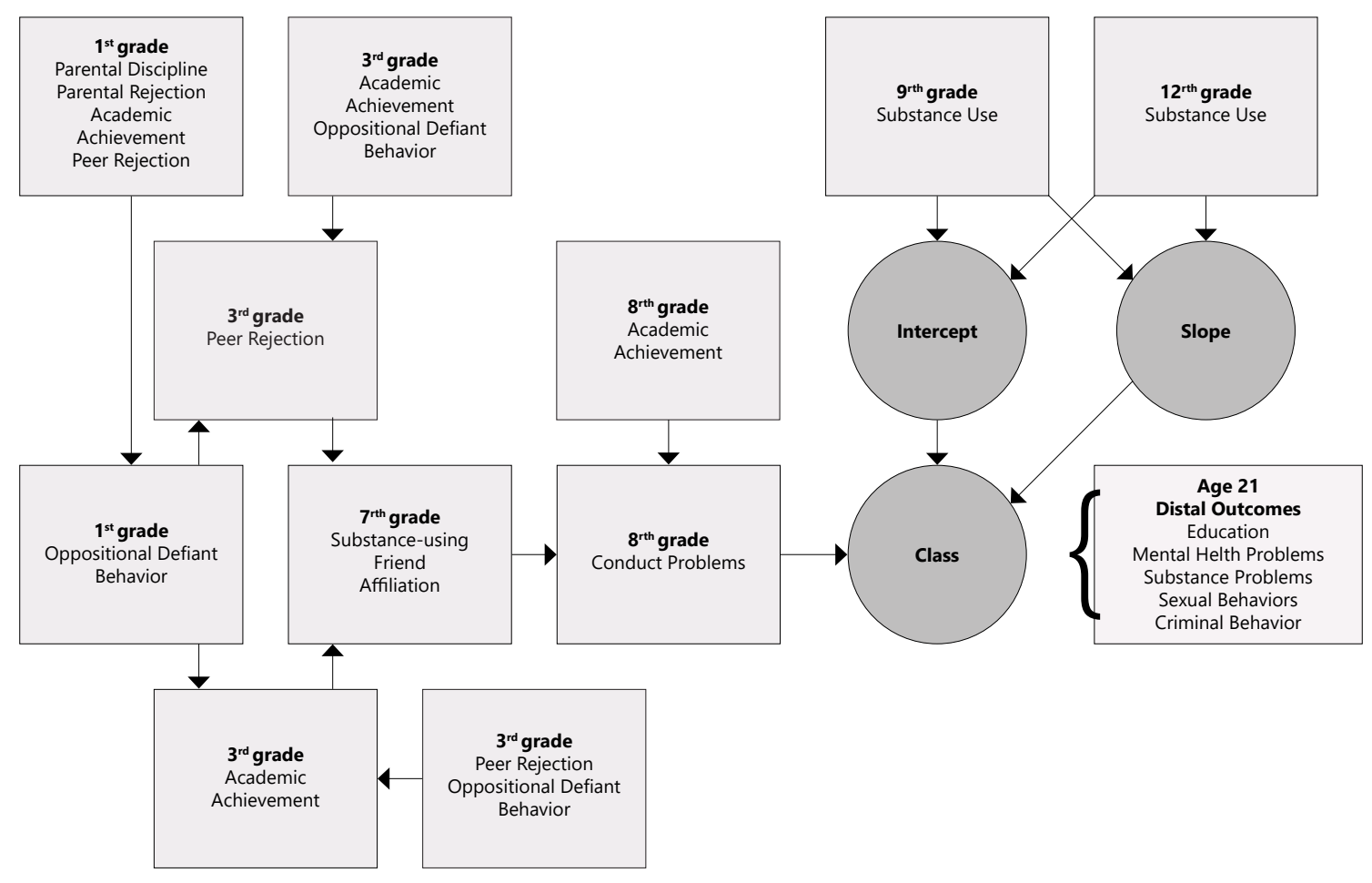

Figure 3 The hypothesized developmental cascade model of high school substance use trajectories. Cross-time correlations not illustrated (Lynne-Landsman, Bradshaw and Ialongo, 2010).

As was seen above, many risk factors and precursors do not have the same effect in different stages of development trajectories, especially if we take into consideration their interaction with other risk and protective factors, which can act either as enhancers or neutralizing agents, i.e. they can be taking over the role of a moderating factor. This means that prevention programs aimed at different developmental phases must also be different and must be targeted at the risk factors that have the biggest effect at each of these phases. Developing a hypothesized model of risk and protective factors is a major challenge, taking into account of all factors which are at play on the micro, meso and macro levels, and their mutual interaction. 
Based on the review of current literature and the above-mentioned models on the subject, we decided to suggest a hypothesized model of developmental psychopathology of drug use and addiction in order to conduct a screening of the current state of selective prevention programs in Croatia. Furthermore, this model would allow us to see to what extent these individual programs rely on the principles of developmental psychopathology (Figure 4). These studies show that certain factors are important only in certain developmental periods, early childhood (e.g. mothers' depression, parents' substance abuse and deviance, individual factors and family relationship quality), while other factors pose a risk for healthy development, temporary use and drug addiction (e.g., individual factors, family interaction, school factors and peers) throughout middle and late adolescence.

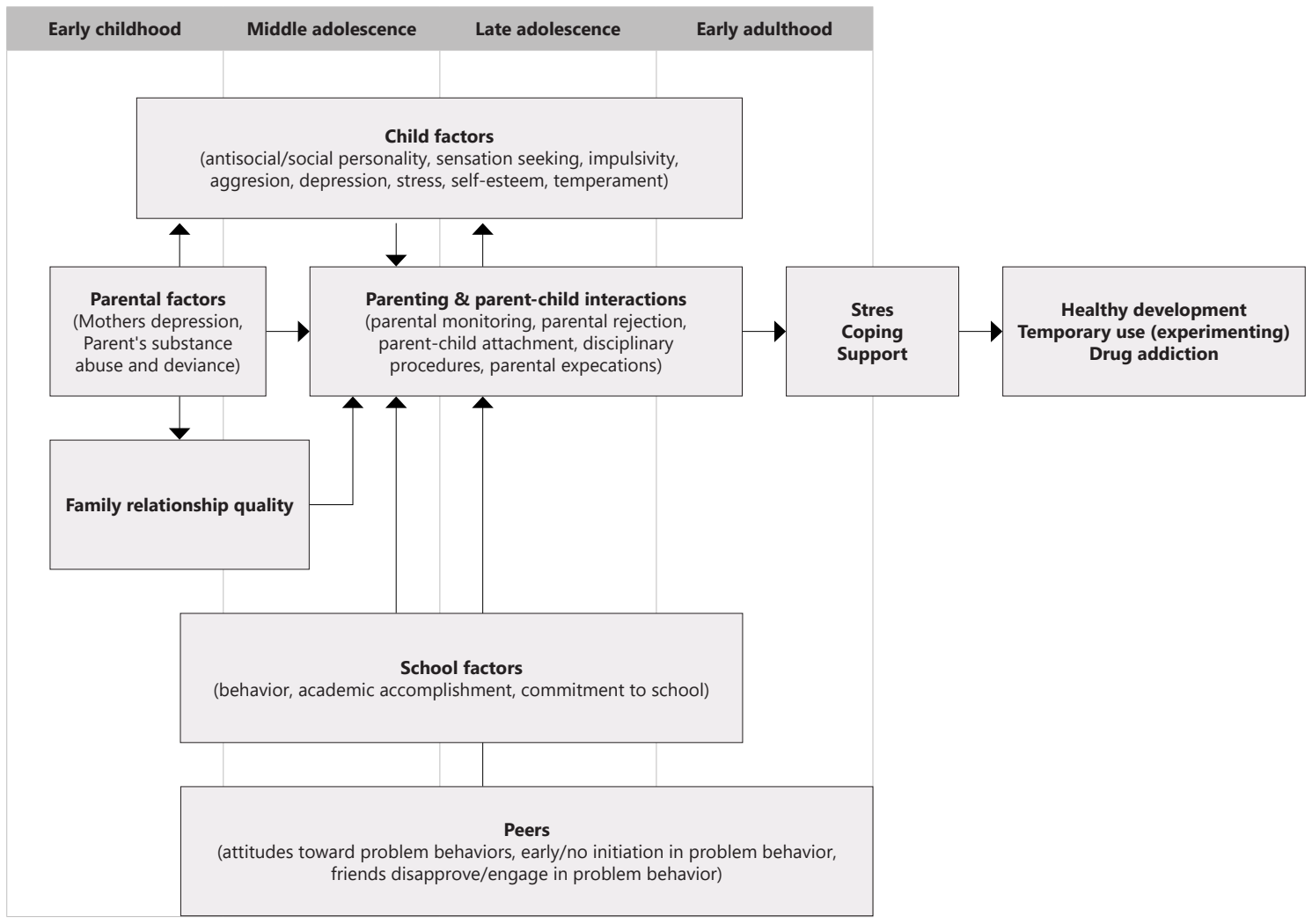

Figure 4 The suggested model of development of drug abuse/addiction in adolescence

In accordance with the above-mentioned theoretical mechanisms, different factors are associated with different developmental periods (Figure 4). Factors are generalized to a certain aspect of an individual's life. Some risk and protective factors are static, i.e. they cannot be changed (e.g. early age of the first substance consumption, for pupils who have already consumed some substance). Even though an intervention cannot directly affect those factors, they can be used for identifying groups that bear a higher risk of developing drug abuse and addiction problems. In this paper, the focus is placed on these selective preventive programs. Selective preventive programs are targeted to individuals or a subgroup of the population whose risk of developing a certain mental or behavioral disorder is significantly higher than average (Mrazek \& Haggerty, 1994). The aim of this paper is to provide an analysis of the current state of selective prevention practice in Croatia, offer a hypothesized model of the development of addiction problems in adolescence 
from the perspective of developmental psychopathology, and provide some guidelines for further development of selective prevention policy and practice in the field of substance abuse prevention.

\section{Methodology}

In order to analyze the state of selective prevention efforts in Croatia, an analysis of the available data has been conducted. Namely, an overview of preventive programs is available merely via Office for Combating Drug Abuse, which runs a Database of projects and programs administered in the field of drug-demand reduction. On the day of June 26th, 2016, there were 531 prevention programs in the Database. These programs were analyzed and compared to the definition of selective prevention put forward by Mrazek \& Haggerty (1994). After this step, we identified 57 selective prevention programs. The programs' descriptions were analyzed with the aim of determining the extent to which they correspond to the components of the definition of a well-operational program, in accordance with the criteria of the US Department of Health and Human Services (US DHHS, 2013a \& 2013b). We have analyzed whether a particular program has:

1. The definition of the problem

2. An identified relevant risk, as well as protective and promotive factors

3. A clear description of the context for the program (clearly articulated principles, values and inclusion criteria of the program for the intended population)

4. A defined strategy, which is most likely to influence targeted results

5. A clear description of the core components that define the program and are judged as being necessary to produce outcomes in a typical service setting (e.g. use of modeling, practice, and feedback to acquire parenting skills)

6. A description of the ingredients that operationally define the core components

7. An elaborated logical model

8. A practical assessment of the performance of the practitioners and its associated core components

9. Methods of testing the elements of an evidence-informed program

Programs which contain at least half of these components were used for further analysis. Finally, only 15 prevention programs remained, and their components were compared to the suggested hypothesized model of developmental psychopathology of drug use and addiction (Figure 3).

\section{Results}

Many specific risk and protective factors were mentioned in the program overview, but program goals and activities did not often focus on them. Table 1 contains all of the specific elements from the suggested model (see Figure 4) and the number of programs which targeted these specific elements. As can be seen, most of the programs focus on individual risk and protective factors, 
and very few programs target risk factors related to the school. The most commonly targeted risk factors were impulsivity ( 9 programs) and antisocial personality traits ( 8 programs). Protective factors that programs addressed the most were pro-social attitudes of peers ( 9 programs) and high self-esteem (8 programs). No program targeted mother's depression or the depression of the children, the early initiation of peers in problem behavior, antisocial behavior in schools, or the lack of commitment to school. Parent-teacher cooperation and school-work transition programs as protective factors were not found in any of the analyzed programs.

\section{Table 1 Number of selective prevention programs containing specific elements from the} suggested model $(N=15)$.

\begin{tabular}{|c|c|c|c|}
\hline \multirow[t]{10}{*}{ Family } & - Parents substance abuse and deviance (2) & - Chohesive family unit (5) & \\
\hline & - Low parental monitoring (3) & - Parent child attachment (3) & \\
\hline & - Parental rejection (2) & - Aduld monitoring/supervision (3) & \\
\hline & - Parent child attachment (4) & - Consistent, age-appropriate discipline (3) & \\
\hline & - Poor disciplinary procedures (3) & & \\
\hline & - Mothers' depression & & \\
\hline & - Low parental expetations (3) & & \\
\hline & - Low family relationship quality (5) & & \\
\hline & & & - Early chilhood (3) \\
\hline & & & - Middle adolesc. (15) \\
\hline \multirow[t]{6}{*}{ Child factors } & - Stress (8) & - High self-esteem (8) & - Late adolescence (11) \\
\hline & - Depression & - Low impulsivity (2) & - Early adulthood (3) \\
\hline & - Aggression (7) & - Easy temperament (2) & \\
\hline & - Impulsivity (9) & & \\
\hline & - Sensation seeking (1) & & \\
\hline & - Antisocial personality (8) & & \\
\hline \multirow[t]{3}{*}{ Peer } & - Favorable attitudes toward problem behaviors (3) & - Friends do not engage in problem behavior (3) & \\
\hline & - Early initiation in problem behavior (2) & - Pro-social attitudes (9) & \\
\hline & - Friends engage in problem behavior (2) & - Friends disapprove of problem behavior (3) & \\
\hline \multirow[t]{3}{*}{ School } & - Antisocial behavior & - Parent-teacher cooperation & \\
\hline & - Academic failure (1) & - Specialized instructions for at-risk students (6) & \\
\hline & - Lack of commitment to school & - School-work transition programs & \\
\hline
\end{tabular}

Most of the programs concerned youth during middle (15 programs) and late adolescence (11 programs), while only some comprised young children (3 programs) or early adults (3 programs).

\section{Discussion}

Most of the prevention efforts in Croatia are school-based and those programs are mostly at the universal level, which is satisfactory for the general population at this developmental stage. The results of this analysis show that there is a shortage of selective prevention programs for adolescent substance use in Croatia, and that the population which is at risk of developing substance use problems is fairly neglected. As can be seen from the results of this analysis the selective prevention programs that do exist are mostly focused on the students' characteristics, but the parents are only seldom targeted. A total of five programs have activities directed at parents of young people at risk. Those programs that targeted families were focused on the quality of relationships in the 
family and the cohesiveness of the family, or on parental interactions (discipline, monitoring, expectations, and attachment). No program targeted maternal depression as a risk factor even though maternal depression has been linked to an increased risk of substance use disorders in offspring (Tartter, Hammen \& Brennan, 2014). The finding that there are no selective prevention programs that target children of depressed mothers is not surprising because, in general, there are very few programs in Croatia that are aimed at children of parents with a mental illness.

When speaking about individual risk and protective factors, many programs target those related to externalizing behavior problems (impulsivity, aggression, antisocial personality traits), but no program targets child/adolescent depression as a risk factor for substance use. This is important since adolescent depression has been significantly associated with substance use (Armstrong \& Costello, 2002), and there is research suggesting that the adolescents may be self-medicating in order to try and cope with their illness on their own (Deykin, Levy \& Wells, 1987).

It is also worth noting that the programs that targeted school-related factors only focused on academic achievement, and that there have been no programs which would try to improve other aspects of school life for children/adolescents at risk, such as school commitment, parent-teacher cooperation, and the transition from school to work. School teachers often say that they do not have the time, energy or skills to focus on the non-academic aspects of school life, but considering these are all programs developed and implemented by non-governmental organizations, it is a shame that the impetus to deal with these topics is not coming from outside of the system at the very least.

In general, it can be concluded that school-related factors and adolescent depression are not at all or are not sufficiently targeted in available prevention interventions in Croatia and that there is little variation in the available prevention programs. There are also few programs for young children which can presumably be attributed to problems in identifying high risk populations.

One important limitation of this analysis is that it relied strictly on the description of the programs in the Database of projects and programs administered in the field of drug demand reduction. The authors of these programs input the information into the program in the database themselves, and this information is not further reviewed. This is a very important deficiency of the database which the Office for Combating Drug Abuse, i.e. the Government should rectify so that the data from the database can be of greater use to professionals and researchers in this field. Since no analyzed program had a clearly defined logical model, we were only able to judge the presence of individual elements of the model in certain programs and not the actual interactions between certain elements and the developmental stage they were targeting. The lack of monitoring and review was also apparent in the fact that many of the programs in the database were not programs in the strict sense of the word and had to be omitted from further analysis. Croatian prevention efforts are in general characterized by a hyperproduction of programs that lack logical modeling and rigorous evaluation. Further, there is a lack of proper analysis of these programs. These kinds of evaluations and reviews would be of great help in future assessments of the state of selective prevention programs aimed at adolescent substance use in Croatia, and would be a logical extension of the work that is already being done by the Office for Combating Drug Abuse of the Republic of Croatia. 


\section{Conclusion}

The perspective of developmental psychopathology can be very useful in creating an all-encompassing strategy of substance use prevention in adolescents. It can be of particular use when creating selective prevention programs because it helps to identify the individuals or subgroups that have a higher risk of developing problems related to substance abuse than others do. By providing information on the relationships between risk and protective factors, and by giving a life-course perspective, it helps us intervene at the right time and in the right setting. The model suggested in this paper is based upon a review of scientific literature, but it should be empirically tested and modified accordingly. Still, analyzing the state of selective prevention efforts in Croatia was useful. This analysis shows that there is ample room for improvement.

The most important suggestions are:

1. There should be a prevention strategy in place which should be based on scientifically demonstrated evidence of development of substance use and addiction problems. It should be created by the Office for Combating Drug Abuse in cooperation with the leading researchers in this field.

2. The Office for Combating Drug Abuse should review the programs that were submitted by the authors and make sure that they were classified correctly, according to the stated level of prevention, target group and targeted risk and protective factors.

3. The quality of the prevention programs that receive public funding programs must be improved: they should have clearly defined logical models that are in line with the prevention strategy. It is crucial that the Office for Combating Drug Abuse continues to provide education for the authors of the programs and that it supports the authors during the application process.

4. More focus should be put on the development of selective prevention programs and on identifying high-risk populations (by means of institutional, financial and educational support by the government).

5. Prevention needs to branch out to other sectors besides schools, and family and community programs should be further incentivized. The centers for social welfare, institutes of public health, and community centers should be supported by the government in the creation, development and implementation of these programs.

6. There should be a greater number of selective prevention programs for young children. This should be encouraged by various institutions on the national, regional and local levels, with additional funding for the creation of these kinds of programs.

7. A greater focus should be placed on children/adolescents with mental health problems. This should be done through a collaboration of the educational, healthcare, and social care systems.

8. The prevention programs should be scientifically evaluated and reviewed often by scientific institutions. Furthermore, the prevention strategy should be updated in order 
to reflect the results of scholarly research. This process should be coordinated by the Office for Combating Drug Abuse. The establishment of the Committee for Quality Assessment of Drug Demand Reduction Projects in 2016 is a step in the right direction and it is expected that the Committee will contribute to the identification and promotion of best-practice programs.

\section{References}

Armstrong, T. D., \& Costello, E. J. (2002). Community studies on adolescent substance use, abuse, or dependence and psychiatric comorbidity. Journal of consulting and clinical psychology, 70(6), 1224.

Barrett, A. E., Turner, R. J. (2006). Family structure and substance use problems in adolescence and early adulthood: examining explanations for the relationship. Addiction, 101(1), 109-120.

Bouillet, D. (2007). Mladi i psihoaktivne supstance: eksperimentiranje ili put u ovisnost. [Youth and psychoactive substances: experimentation or a road to addiction] In V. Ilišin \& F. Radin (Eds.), Mladi: problem ili resurs. [Youth: problem or resource] Zagreb: Institut za društvena istraživanja, 203-235.

Budak, J., Jurlina Alibegović, D., Slijepčević, S., \& Švaljek, S. (2013). Analiza javnih rashoda za praćenje ostvarivanja ciljeva u području suzbijanja zlouporabe droga u Republici Hrvatskoj. [An analysis of public spending on monitoring the goal attainment in the area of combatting drug abuse in the Republic of Croatia] Zagreb: Ekonomski institut i Zagreb: Ured za suzbijanje zlouporabe droga Vlade Republike Hrvatske.

Cicchetti, D., \& Rogosch, F. A. (1996). Equifinality and multifinality in developmental psychopathology. Development and Psychopathology, 8(4), 597-600.

Cicchetti, D., \& Rogosch, F. A. (2002). A developmental psychopathology perspective on adolescence. Journal of consulting and clinical psychology, 70(1), 6.

Croatian Institute for Public Health / Hrvatski zavod za javno zdravstvo (2016). Hrvatski zdravstveno-statistički ljetopis za 2015. godinu. [Croatian health statistics yearbook for 2015] Zagreb: Hrvatski zavod za javno zdravstvo.

Dawes, M. A., Antelman, S. M., Vanyukov, M. M., Giancola, P., Tarter, R. E., Susman, E. J., Mezzich, A., Clark, D. B.(2000). Developmental sources of variation in liability to adolescent substance use disorders. Drug and Alcohol Dependence, 61(1), 3-14.

Department of Health and Human Services (2013a). Best Intentions are Not Enough: Techniques for Using Research and Data to Develop New Evidence-Informed Prevention Programs. ASPE Research Brief. Retrieved from https://aspe.hhs.gov/basic-report/best-intentionsare-not-enough-techniques-using-research-and-data-develop-new-evidence-informedprevention-programs on July 6, 2016.

Deykin, E. Y., Levy, J. C., \& Wells, V. (1987). Adolescent depression, alcohol and drug abuse. American Journal of Public Health, 77(2), 178-182.

ESPAD Group (2016). ESPAD Report 2015: results from the European school survey project on alcohol and other drugs. Lisbon: European Monitoring Centre for Drugs and Drug Addiction (EMCDDA).

European Monitoring Centre for Drugs and Drug Addiction (2017). Croatia, Country Drug Report 2017. Luxembourg: Publications Office of the European Union. 
Glantz, M. D., \& Leshner, A. I. (2000). Drug abuse and developmental psychopathology. Development and Psychopathology, 12(4), 795-814.

Lynne-Landsman, S. D., Bradshaw, C. P., \& lalongo, N. S. (2010). Testing a developmental cascade model of adolescent substance use trajectories and young adult adjustment. Development and psychopathology, 22(04), 933-948.

Martel, M. M., Pierce, L., Nigg, J. T., Jester, J. M., Adams, K., Puttler, L. I., Buu, A., Fitzgerald, H., Zucker, R. A. (2009). Temperament pathways to childhood disruptive behavior and adolescent substance abuse: Testing a cascade model. Journal of Abnormal Child Psychology, 37(3), 363.

Mrazek, P. J., \& Haggerty, R. J. (Eds.). (1994). Reducing risks for mental disorders: Frontiers for preventive intervention research. National Academies Press.

Nation, M., Crusto, C., Wandersman, A., Kumpfer, K. L., Seybolt, D., Morrissey-Kane, E., \& Davino, K. (2003). What works in prevention: Principles of effective prevention programs. American Psychologist, 58(6-7), 449.

National Institute on Drug Abuse (2015). Trends \& Statistics. Retrieved from https://Www. drugabuse. gov/related-topics/trends-statistics on July 7, 2016.

Robins, L. N. (1996). Deviant children grown up. European child \& adolescent psychiatry, 5, 44-46.

Rogosch, F. A., Oshri, A., \& Cicchetti, D. (2010). From child maltreatment to adolescent cannabis abuse and dependence: A developmental cascade model. Development and psychopathology, 22(04), 883-897.

Ross, C. E., Reynolds, J. R., \& Geis, K. J. (2000). The contingent meaning of neighborhood stability for residents' psychological well-being. American Sociological Review, 581-597.

Sameroff, A. J. (1995). General systems theories and psychopathology. In D. Cicchetti \& D. Cohen (Eds.), Developmental psychopathology (Vol. 1), New York: Wiley

Sameroff, A. J., \& Chandler, M. J. (1975). Review of child development research. Review of child development research, 4.

Santor, D. A., Messervey, D., \& Kusumakar, V. (2000). Measuring peer pressure, popularity, and conformity in adolescent boys and girls: Predicting school performance, sexual attitudes, and substance abuse. Journal of youth and adolescence, 29(2), 163-182.

Sitnick, S., Shaw, D. S., \& Hyde, L. (2014). Precursors of adolescent substance use from early childhood and early adolescence: Testing a developmental cascade model. Development and psychopathology, 26(1), 125-140.

Šimetin Pavić, I., Mayer, D., Musić Milanović, S., Jovičić, D. (2016). Istraživanje o zdravstvenom ponašanju učenika: osnovni pokazatelji zdravlja i dobrobiti učenika i učenica u Hrvatskoj. [Health Behaviour in School-aged Children - HBSC] Zagreb: Hrvatski zavod za javno zdravstvo.

Tartter, M., Hammen, C., \& Brennan, P. (2014). Externalizing disorders in adolescence mediate the effects of maternal depression on substance use disorders. Journal of abnormal child psychology,42(2), 185-194.

Townsend, L., Flisher, A. J., \& King, G. (2007). A systematic review of the relationship between high school dropout and substance use. Clinical child and family psychology review, 10(4), 295-317. 
Ured za suzbijanje zlouporabe droga (2015). Nacionalni program prevencije ovisnosti za djecu i mlade u odgojno-obrazovnom sustavu, te djecu i mlade u sustavu socijalne skrbi za razdoblje od 2015. do 2017. godine. [National program for addiction prevention, as aimed towards children and youth in the educational system and the children and youth in the social welfare system, for 2015-2017] Zagreb: Vlada Republike Hrvatske.

US Department of Health and Human Services (2013b). Core Intervention Components: Identifying and Operationalizing What Makes Programs Work. ASPE Research Brief. Retrieved from https://aspe.hhs.gov/basic-report/core-intervention-components-identifying-and-operationalizing-what-makes-programs-work on July 6, 2016.

Van Ryzin, M. J., Fosco, G. M., \& Dishion, T. J. (2012). Family and peer predictors of substance use from early adolescence to early adulthood: An 11-year prospective analysis. Addictive behaviors, 37(12), 1314-1324.

Vlada Republike Hrvatske (2012). Nacionalna strategija suzbijanja zlouporabe droga u Republici Hrvatskoj za razdoblje od 2012. do 2017. godine. [National strategy for the prevention of drug abuse in the Republic of Croatia, for 2012-2017] Zagreb: Vlada Republike Hrvatske.

White, H. R., Xie, M., Thompson, W., Loeber, R., \& Stouthamer-Loeber, M. (2001). Psychopathology as a predictor of adolescent drug use trajectories. Psychology of Addictive Behaviors, 15(3), 210. 